\title{
Study of neonatal jaundice in a tertiary care centre of South India
}

\author{
Sahoo $\mathrm{M}^{1}$, Arigela $\mathrm{V}^{2}$, L Pramitha ${ }^{3}$, Sudarsini $\mathrm{P}^{4}$, Rao $\mathrm{KU}^{5}$ \\ ${ }^{1}$ Dr Manas Ranjan Sahoo, Associate Professor, ${ }^{2}$ Dr Vasundhara Arigela, Professor, ${ }^{3}$ Dr Lankala Pramitha, Post Graduate, \\ ${ }^{4}$ Dr Padala Sudarsini, Professor \& HOD, ${ }^{5}$ Dr K Umamaheswar Rao, Professor \& Principal, all authors are affiliated with \\ Department of Pediatrics, ASRAM Medical College, Eluru, AP, India.
}

Address for Correspondence: Dr Manas Ranjan Sahoo, Assistant Professor, Department of Pediatrics, ASRAM Medical College, Eluru, AP. Mail Id: drmrsahoo@ gmail.com

\begin{abstract}
Hyperbilirubinemia is a common problem during the neonatal period occurring in up to $60 \%$ of term and $80 \%$ of preterm babies in the first week of life. Some of the most common causes of neonatal jaundice include physiological jaundice, breast feeding or non feeding jaundice, breast milk jaundice, prematurity and $\mathrm{ABO}$ incompatibility. Aims and objectives of study: To study the incidence, various risk factors in newborns with clinical jaundice progressing to jaundice needing treatment and to assess no of neonates requiring phototherapy \& exchange transfusion in ASRAM hospital, during May 2013 to July 2014. Method: The present study was a prospective hospital based study involving all neonates who were born at ASRAM Medical College and Hospital, a tertiary care centre, Eluru, West Godavari District, Andhra Pradesh. Observation: Out of 560 newborns, 273 (48.8\%) newborns developed clinical jaundice. Out of 273 newborns with clinical jaundice, 166 (61\%) newborns developed physiological jaundice and 107 (39\%) newborns developed non physiological jaundice requiring therepeutic intervention in the form of phototherapy or exchange transfusion. Conclusion: Present study concludes that the leading cause of pathological jaundice is breastfeeding jaundice, ABO incompatibility and prematurity.
\end{abstract}

Keywords: Hyperbilirubinemia, Non physiological jaundice, $\mathrm{ABO}$ incompatibility.

\section{Introduction}

Hyperbilirubinemia is a common problem during the neonatal period occurring in up to $60 \%$ of term and $80 \%$ of preterm babies in the first week of life. [1,2]. Some of the most common causes of neonatal jaundice include physiological jaundice, breast feeding or non feeding jaundice, breast milk jaundice, prematurity leading to jaundice \& various pathological causes like haemolytic disease, liver dysfunction, neonatal sepsis, deficiency of G6PD enzyme, hypothyroidism and rare conditions such as Gilbert's syndrome etc $[3,4]$. Extreme hyperbilirubinemia is rare, however, if left untreated especially in premature infant, indirect hyperbilirubinemia may lead to kernicterus, a serious neurological problem and social \& economic burden on the patient's family \& society. Elevation of direct bilirubin constitute the pathological causes of jaundice \& should be promptly treated either by medical or surgical means.

Manuscript received: $15^{\text {th }}$ July 2016

Reviewed: $27^{\text {th }}$ July 2016

Author Corrected; $9^{\text {th }}$ August 2016

Accepted for Publication: $19^{\text {th }}$ August 2016
Aims and objectives of the study- To study the incidence, various risk factors in newborns with clinical jaundice progressing to jaundice needing treatment and to assess number of neonates requiring phototherapy \& exchange transfusion in ASRAM hospital, during May 2013 to July 2014.

\section{Materials and Methodology}

The present study was a prospective hospital based study involving all neonates who were born at ASRAM Medical College and Hospital, a tertiary care centre, Eluru, West Godavari District, Andhra Pradesh. The present study was conducted from May 2013 to July 2014 over a period of 14 months. A predesigned proforma has aided the enrollment of newborns into the study. Significant hyperbilirubinemia was defined as the value of bilirubin according to AAP guidelines in term neonates and Cockington's charts in preterm, above which phototherapy or exchange transfusion or both are required [5,6]. Clinical jaundice is visible yellowish discoloration of skin of newborns in day 
light. The following situations suggest non physiologic jaundice and require evaluation (onset of jaundice occurs before 24 hours of age, elevation of serum bilirubin requires phototherapy, a rise in serum bilirubin levels of $0.2 \mathrm{mg} / \mathrm{dl} / \mathrm{hour}$, signs of underlying illness in any infant (vomiting, lethargy, poor feeding, excessive weight loss, apnea, tachypnea or temperature instability), jaundice persisting after 8 days in a term baby or after 14 days in a premature infant.[7]

\section{Inclusion Criteria}

All babies born at ASRAM who were admitted to NICU and postnatal ward, who had clinical jaundice irrespective of the gestational age and birth weight were included in the present study.

\section{Exclusion Criteria}

\section{Results}

In the present study, out of 560 newborns delivered during the study period at ASRAM, 273 (48.8\%) newborns developed clinical jaundice.

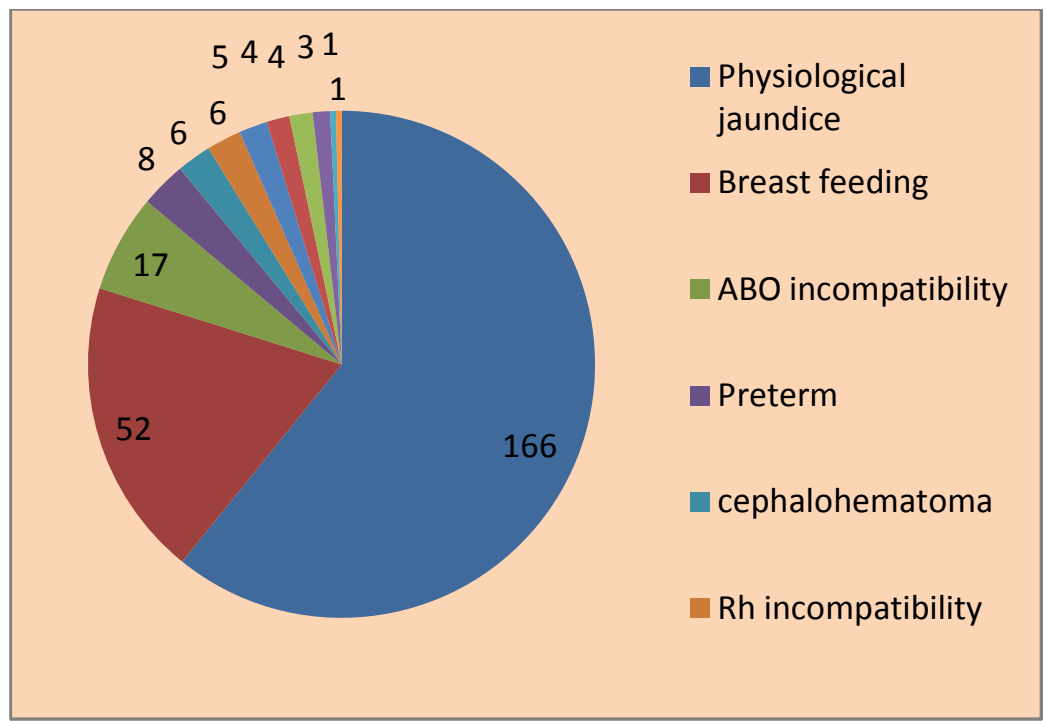

Out of 273 newborns with clinical jaundice, 166 (61\%) newborns developed physiological jaundice. The overall incidence of non physiological jaundice in the study group is 19\%. (107 out of 560 newborns).

Out of 273 newborns with clinical jaundice, 107 newborns developed pathological jaundice. Out of 107 newborns, 52 (48\%) newborns had breast feeding jaundice. 17 (16\%) newborns had ABO incompatibility. 8 (7.54\%) newborns were preterms. $6(5.7 \%)$ newborns had cephalohematoma. $6(5.7 \%)$ newborns had Rh incompatibility. 5 (4.8\%) newborns had history of previous sibling deaths. $4(3.8 \%)$ newborns had history of birth asphyxia. $4(3.8 \%)$ newborns were born to mothers with history of GDM.3 $(2.8 \%)$ newborns had sepsis. $1(0.93 \%)$ newborn was born to mother with history of hypothyroidism. $1(0.93 \%)$ newborn was born to mother with TORCH infection.

Sex factor had an influence on the incidence of non physiological jaundice among the neonates showing that males $67 \%$ (72 out of 107) had higher incidence compared to females 33\% (35 out of 107) with with p value $<0.05$. All 4 (100\%) newborns with history of birth asphyxia developed pathological jaundice. 
Out of 107 babies with pathological jaundice, 5 newborns had Rh incompatibility, 17 newborns had ABO incompatibility, 1 newborn had both $\mathrm{Rh}$ and $\mathrm{ABO}$ incompatibility.

Out of 273 newborns with clinical jaundice, $2(1 \%)$ newborns required double volume exchange transfusion as a therapeutic intervention for the treatment of jaundice. Both these cases were associated with Rh incompatability as a risk factor for pathological jaundice.

\section{Discussion}

Incidence of clinical jaundice in the present study population is $49 \%$. In a study done by Kumar RK in 1999, jaundice was the most common condition requiring medical attention in newborn infants. About 50 percent of term and 80 percent of preterm infants developed jaundice in the first week of life [8].

In the present study the overall incidence of non physiological jaundice is 19\% (107 out of 560). In a study conducted by Anil Narang et al. in 1996 at Nehru hospital, Chandigarh, of 3791 live births, 551 (14.5\%) developed neonatal jaundice needing therapeutic intervention, i.e., either phototherapy or exchange transfusion. [9] Significant male preponderance was seen in our study male being $67 \%$ vs female babies with $33 \%$ in non physiological jaundice.

In a study from Chandigarh done by Narang et al, incidence of hyperbilirubinemia in males was $64.2 \%$. [6] In another study done at Delhi by Singhal et al, incidence of hyperbilirubinemia in males was $56.8 \%$. [10]

Among them most common cause of jaundice was breast feeding jaundice 52 (48\%), second most common cause being due to ABO incompatibility 17 (16\%), third common cause being due to newborns were prematurity 8 (7.54). In a study conducted by May-Jen Huang et al., similar patten of distribution has been observed [11]

Breastfeeding jaundice tops the list in nonphysiological jaundice. In a study done by Osborn LM et al, it was found that Breastfed newborns may be at increased risk for early-onset exaggerated physiologic jaundice because of relative caloric deprivation in the first few days of life [12].

In another study done by Schneider AP, it was stated that decreased volume and decreased frequency of feedings may result in mild dehydration and the delayed passage of meconium. Compared with formula-fed newborns, breastfed infants are three to six times more likely to experience moderate jaundice (total serum bilirubin level above $12 \mathrm{mg}$ per dL) [13].
ABO incompatibility has become the second most common cause of non physiological jaundice in newborn in our study.

In a study of a population of newborns in Turkey, there was a $14.8 \%$ incidence of $\mathrm{ABO}$ incompatibility, with $21.3 \%$ of these babies exhibiting significant hyperbilirubinemia and $4.4 \%$ exhibiting severe $\mathrm{ABO}$ hemolytic disease [14].

Prematurity was third most common cause in our study. Preterm new borns are prone to developing jaundice due to immaturity of bilirubin conjugating system, higher rate of hemolysis, increased enterohepatic circulation, decreased caloric intake [15]. Onyearugha, et al concluded prematurity as the second leading cause of neonatal jaundice [16].

$2 \%$ (6) newborns had extravascular bleed and all 6 newborns developed pathological jaundice. In a study done by Meredith L. Porter et al at Dewitt Army Community Hospital, Fort Belvoir, Virginia, they found that Common risk factors for hyperbilirubinemia include fetal-maternal blood group incompatibility, prematurity, and a previously affected sibling, Cephalohematoma, bruising, and trauma from instrumental delivery may increase the risk for serum bilirubin elevation [17].

All 5 newborns with history of previous sibling death developed pathological jaundice. In a study done by Meredith L. Porter et al in Dewitt Army Community Hospital, Fort Belvoir, Virginia, Common risk factors for hyperbilirubinemia included fetal-maternal blood group incompatibility, prematurity, and a previously affected sibling. Infants with risk factors should be monitored closely during the first days to weeks of life [17].

4 newborns with history of birth asphyxia developed pathological jaundice. Out of 273 newborns with clinical jaundice, 107 (39\%) newborns required therapeutic intervention in the form of phototherapy as a mode of treatment for clinical jaundice. 


\section{Conclusions}

Present study concludes that the leading cause of non physiological jaundice is breastfeeding jaundice followed and $\mathrm{ABO}$ incompatibility and prematurity. Physiological jaundice contributes maximum number of cases among total cases.

\section{Funding: Nil, Conflict of interest: Nil Permission from IRB: Yes}

\section{References}

1. Slusher TM, Angyo IA, BodeTF. Transcutaneous bilirubin measurements and serum total bilirubin levels in indigenous African infants. Pediatrics 2004; 113: 1636-1641.

2. Haque KM, Rahman M. An unusual case of ABOhaemolytic disease of the newborn. Bangladesh Med Res Counc Bull. 2000 Aug;26(2):61-4.

3. Madan A, James RM, Stevenson DK. Neonatal Hyperbilirubinemia. In: Taeusch HW, Ballard RA, Gleason CA. Avery's diseases of the new born. 8th Ed. Elsevier Saunders 2004: 1226-1256.

4. Laforgia N, Faienza MF, Rinaldi A, D'Amato G, Rinaldi G, Iolascon A. Neonatal hyperbilirubinemia and Gilbert's syndrome. J Perinat Med. 2002;30(2):166-9.

5. American Academy of Pediatrics Subcommittee on Hyperbilirubinemia. Management of hyperbilirubinemia in the newborn infant 35 or more weeks of gestation. Pediatrics. 2004 Jul;114(1):297-316.

6. Cockington RA. A guide to the use of phototherapy in the management of neonatal hyperbilirubinemia. $\mathbf{J}$ Pediatr. 1979 Aug;95(2):281-5.

7. Mary Lucia P.Gregory, Camilia R. Martin, John P. Cloherty . Neonatal Hyperbilirubinemia. In:John P. Cloherty,Eric C. Eichenwald, Anne R. Hansen, Ann R. Stark. editors. Manual of neonatal care. $7^{\text {th }}$ edition, Philadelphia: Lippincott Willams and Wilkins; 2012. Chapter 26, p. $304-339$
8. Kumar RK. Neonatal jaundice. An update for family physicians. Aust Fam Physician. 1999 Jul;28(7):679-82.

9. Narang A, Gathwala G, Kumar P. Neonatal jaundice: an analysis of 551 cases. Indian Pediatr. 1997 May;34(5):429-32.

10. Singhal PK, Singh M, Paul VK, Deorari AK, Ghorpade MG. Spectrum of neonatal hyperbilirubinemia: an analysis of 454 cases. Indian Pediatr. 1992 Mar;29(3):319-25.

11. Huang MJ, Kua KE, Teng HC, Tang KS, Weng HW, Huang CS. Risk factors for severe hyperbilirubinemia in neonates. Pediatr Res. 2004 Nov; 56(5):682-9. Epub 2004 Aug 19.

12. Osborn LM, Reiff MI, Bolus R. Jaundice in the fullterm neonate. Pediatrics. 1984 Apr;73(4):520-5.

13. Schneider AP 2nd. Breast milk jaundice in the newborn. A real entity. JAMA. 1986 Jun 20;255 (23):3270-4.

14. Sarici SÜ, Yurdakök M, Serdar MA, et al. An early (sixth-hour) serum bilirubin measurement is useful in predicting the development of significant hyperbilirubinemia and severe $\mathrm{ABO}$ hemolytic disease in a selective high-risk population of newborns with $\mathrm{ABO}$ incompatibility. Pediatrics 2002; 100(3):600-611.

15. Chan M. Neonatal Jaundice: In Stanfield P, Brueton M, Chan M, Parkin M. (Eds) Diseases of children in the tropics and subtropics (4th Edition) London. Edward Arnold. 1994:221-8.

16. Onyearugha $\mathrm{CN}$, Onyire $\mathrm{BN}$, Ugboma HA. Neonatal Jaundice: Prevalence and associated factors as seen in Federal Medical Center Abakaliki, Southeast Nigeria. J Clin Med Res. 2010;3:40-45.

17. Porter ML, Dennis BL. Hyperbilirubinemia in the term newborn. Am Fam Physician. 2002 Feb 15;65 (4):599-606.

\section{How to cite this article?}

Sahoo M, Arigela V, L Pramitha, Sudarsini P, Rao KU. Study of neonatal jaundice in a tertiary care centre of South India. Int J Pediatr Res.2016;3(8):585-588.doi:10.17511/ijpr.2016.i08.07 